\title{
Nematode Management in Sweet Potatoes (including Boniatos) ${ }^{1}$
}

\author{
Z. J. Grabau and J. W. Noling ${ }^{2}$
}

The primary intended audience is agricultural professionals involved in commercial sweet potato production directly or through advising roles (Extension agents, producers, crop consultants, academics, etc.). The purpose is to guide professionals in improving nematode management in sweet potato production. Similar to other EDIS nematode management guides, it is intended to give a concise but relatively comprehensive summary of relevant information to understand and manage nematodes in this crop in Florida.

\section{Sweet Potato Production in Florida}

Florida is an important sweet potato (Ipomoea batatas) producer with 812 million pounds produced in 2018, ranking sixth in the United States (USDA 2020). Production includes both conventional and Boniato type sweet potatoes. Conventional sweet potatoes have high sugar content, typically with orange flesh. Boniato sweet potatoes have white flesh that is drier with more starch and less sugar. Boniatos are common in south Florida, in part because they are popular in Cuban cuisine prevalent in that area. In Florida, most conventional sweet potatoes are grown in the north-central region with some production emerging in northeast Florida. Crop-nematode interactions and nematode management are similar for both types of sweet potato except where noted. For further information on sweet potato production in Florida, see the latest root crop production chapter in the UF/IFAS Vegetable Production Handbook (Dittmar et al. 2020).

\section{Plant-Parasitic Nematodes}

Plant-parasitic nematodes are microscopic roundworms that feed on plant tissue. Most plant-parasitic nematodes live in the soil and attack the roots of plants. This can reduce yield by reducing plant growth and disfiguring sweet potato storage roots (the fleshy, tuberous roots that are the marketable product), which reduces or eliminates marketable value. Southern root-knot nematode (Meloidogyne incognita) is the most common and important nematode pest of sweet potato (Ipomoea batatas) in the Southeast, and likely Florida. Javanese root-knot nematode (Meloidogyne javanica) is also common in Florida and can damage sweet potato. The invasive guava root-knot nematode (Meloidogyne enterolobii) - concerning for its ability to overcome nematode-resistant sweet potato cultivars-is also present in Florida, but its prevalence in Florida sweet potato production is unknown. The reniform nematode (Rotylenchulus reniformis) can also be damaging to sweet potato, but in Florida is limited primarily to the Panhandle and far south. This is due to its preference for heavier soils and proliferation on cotton, a crop common in the Florida Panhandle. Sting nematode (Belonolaimus longicaudatus) is damaging to a wide range of crops and is prevalent in northeast Florida where sweet potato production is

1. This document is ENY-030 (formerly RF-NG030), one of a series of the Entomology and Nematology Department, UF/IFAS Extension. Original publication date March 1997. Revised December 2009, December 2012, December 2016, and October 2021. Visit the EDIS website at http://edis.ifas. ufl.edu for the currently supported version of this publication.

2. Z. J. Grabau, assistant professor, Entomology and Nematology Department; J. W. Noling, professor emeritus, Entomology and Nematology Department; UF/IFAS Citrus Research and Education Center; UF/IFAS Extension, Gainesville, FL 32611.

The Institute of Food and Agricultural Sciences (IFAS) is an Equal Opportunity Institution authorized to provide research, educational information and other services

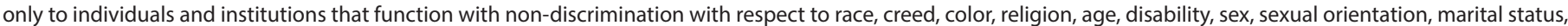

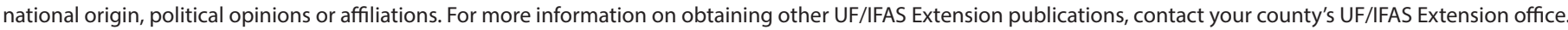
U.S. Department of Agriculture, UF/IFAS Extension Service, University of Florida, IFAS, Florida A \& M University Cooperative Extension Program, and Boards of County Commissioners Cooperating. Nick T. Place, dean for UF/IFAS Extension. 
increasing. Preliminary observations suggest sting nematode can be damaging to sweet potato, but the relationship is still being investigated. For more information about these nematodes, see the following publications on sting nematode (Crow 2018) and reniform nematode (Wang 2019). Several other nematodes are associated with sweet potato, but their impact on yield in Florida is either low or unknown.

Plant-parasitic nematodes can be grouped based on their feeding habits, and this can be an important factor in diagnostics and management. Nematode life stages include the egg, four pre-adult juvenile stages, and a mature adult stage. All plant-parasitic nematodes have a stylet, which is a needle-like mouthpart that is typically hollow and used to draw nutrients from the host plant. Migratory ectoparasites (Figure 1) are mobile (migratory), and only their stylet enters the root while feeding; the rest of the body remains outside (ectoparasite). These nematodes move from one root feeding site to another. Sting nematodes are migratory ectoparasites. Migratory endoparasites are mobile and move from site to site when feeding, but fully enter the root to feed. Lesion nematode (Pratylenchus spp.) is an example of a migratory endoparasite (Figure 2). Sedentary endoparasites enter the root to feed, induce the plant to form a complex feeding site, and do not move from this site once established as a juvenile or adult female (Figure 3). The female stage of sedentary endoparasites becomes enlarged as it feeds and produces hundreds of eggs. Root-knot and reniform nematodes are sedentary endoparasites.

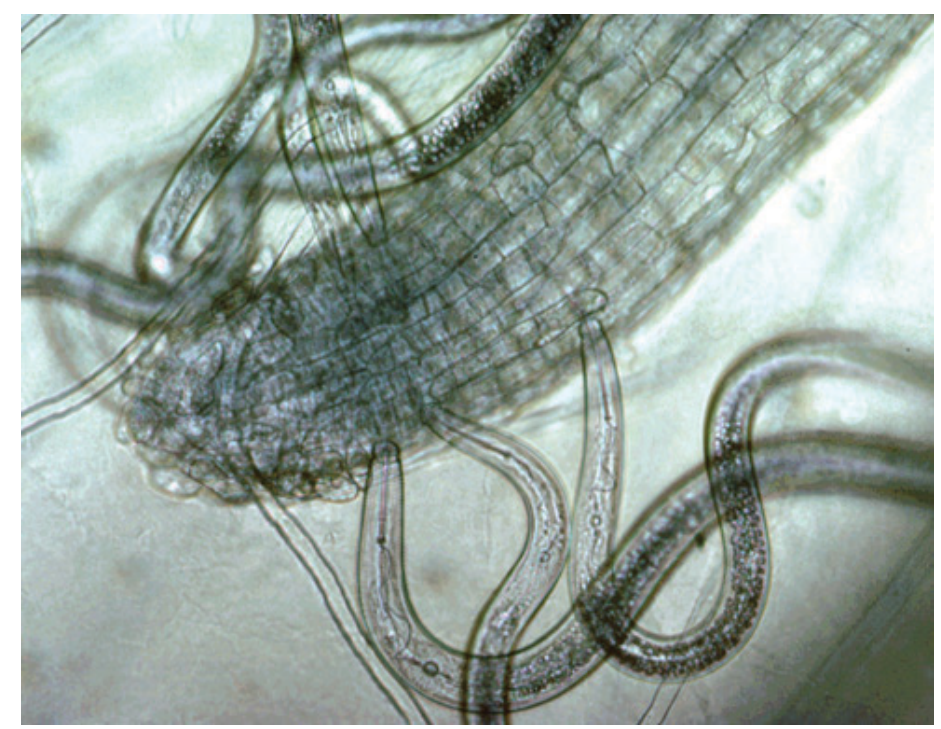

Figure 1. Migratory ectoparasites (sting nematode pictured here) insert their stylets to feed, leaving their bodies outside the root. Credits: Ole Becker, University of California Riverside. Used with permission.

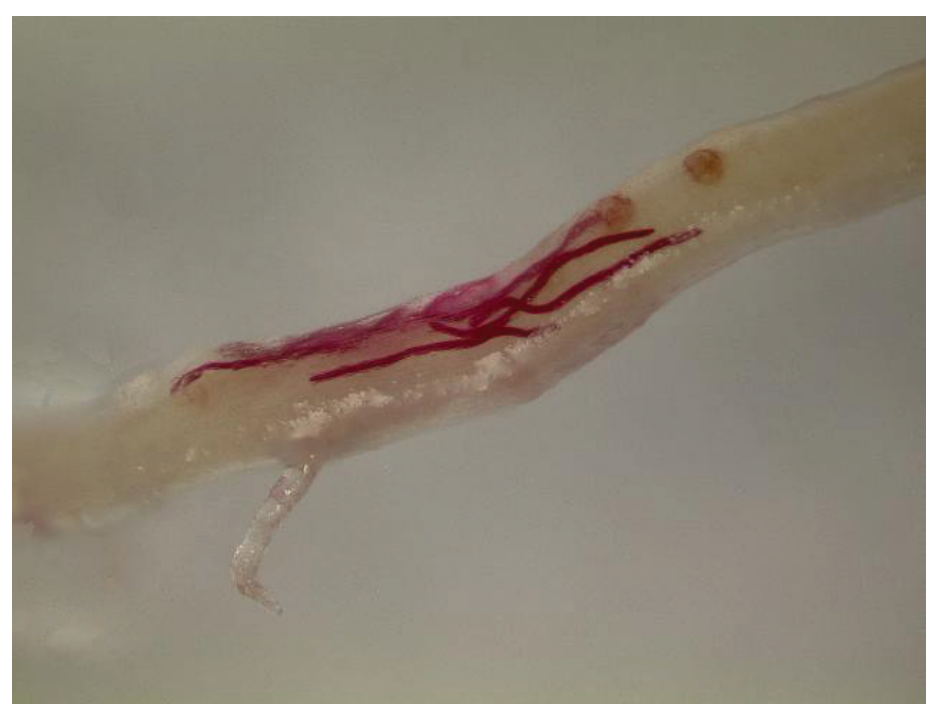

Figure 2. Migratory endoparasites feed with their bodies inside the root and move from site to site in the root to feed. Generally, all life stages are of a relatively similar size.

Credits: A.C. Hixson, UF/IFAS

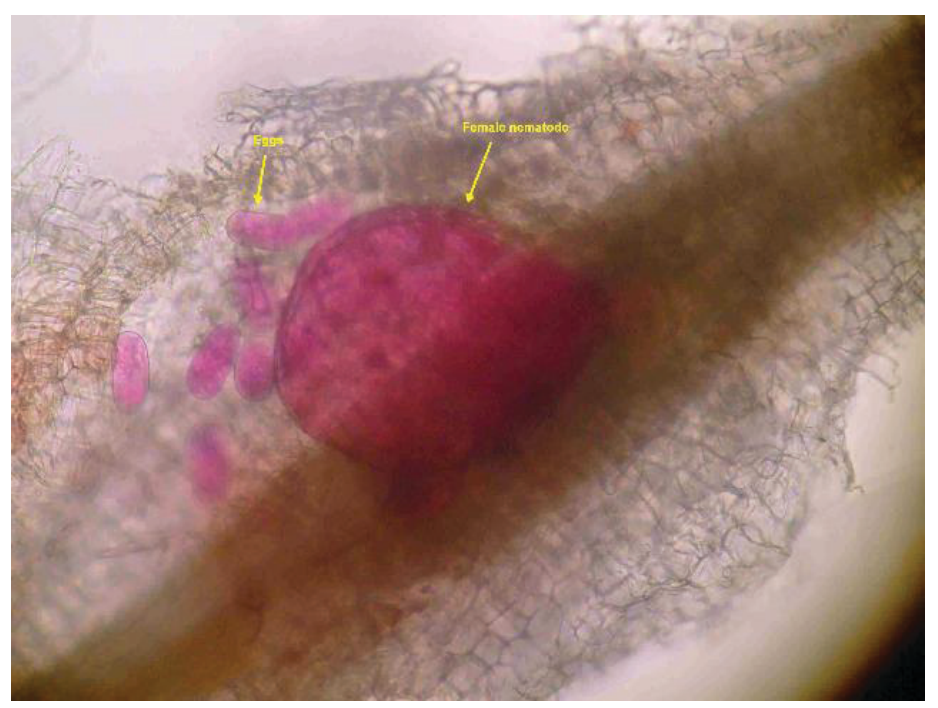

Figure 3. Sedentary endoparasites (root-knot nematode pictured here) establish a complex feeding site in the root as a juvenile or immature female and do not move from that site for the rest of their lives. Adult females enlarge as they feed and produce eggs.

Credits: N.S. Sekora, UF/IFAS

\section{Symptoms and Damage}

Monitor for symptoms to spot potential nematode problems. Subsequent confirmation by sampling, as described in the next section, is generally necessary. Additionally, yield loss from nematodes can occur in the absence of obvious symptoms, so routine sampling is an important complement to scouting for symptoms. Foliar symptoms of nematode infestation generally involve stunting, wilting, leaf chlorosis (yellowing), and other symptoms indicating nutrient deficiency (Figures 4 and 5). Nematode-infested fields may have poor vine canopy coverage (Figures 6 and 7) due to delayed or reduced vine growth. In severe cases, plant parts may die and turn brown (necrosis), or entire 
plants may die, resulting in reduced stand. Plants exhibiting stunt or decline symptoms usually occur in patches of nonuniform growth (Figure 8) rather than evenly throughout a field and correspond to varying nematode abundances and environmental conditions (soil type, moisture, fertility).

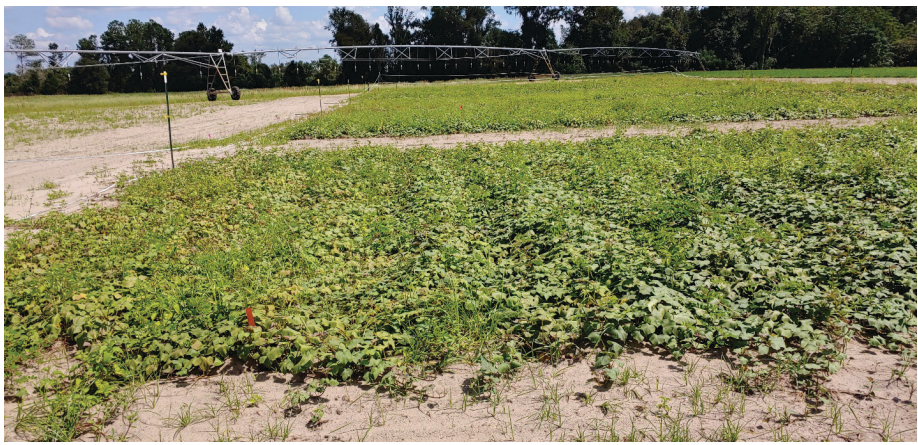

Figure 4. Patchy leaf chlorosis (bottom left) and generalized wilting in a field trial with severe root-knot nematode infestation. Credits: Zane Grabau, UF/IFAS

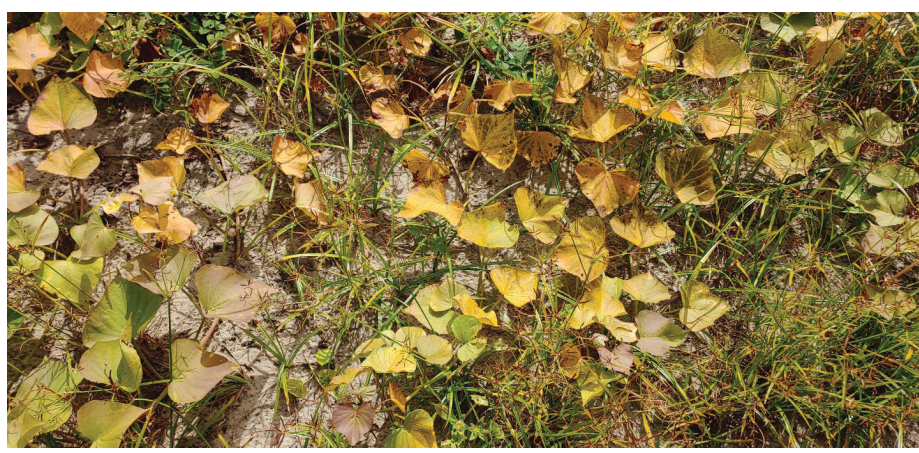

Figure 5. Severe leaf chlorosis (yellowing) and other discoloring late in the season in a field with severe southern root-knot nematode infestation.

Credits: Zane Grabau, UF/IFAS

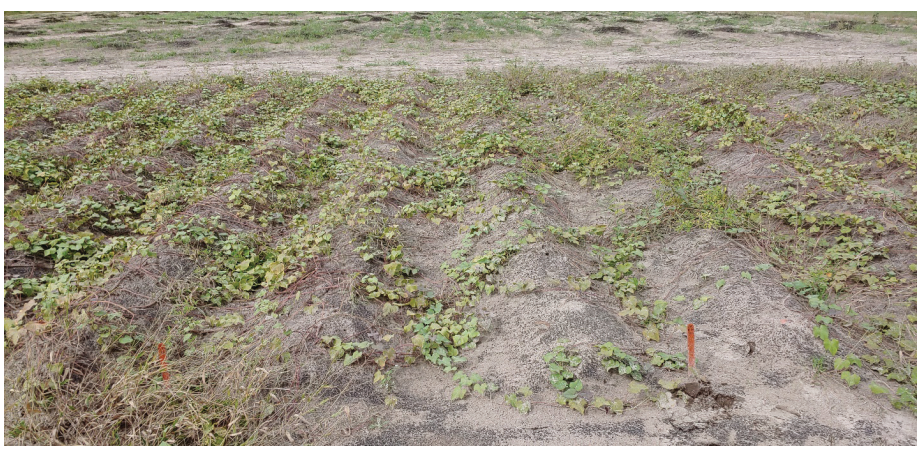

Figure 6. Poor vine coverage and vigor late in the season in a trial with severe southern root-knot nematode infestation and poor soil fertility. Credits: Zane Grabau, UF/IFAS

Belowground symptoms caused by nematodes may show up on storage roots or fibrous roots-any smaller root not swollen into a storage root. Galling-irregular swelling of fibrous roots (Figures 9 and 10) or storage roots (Figure 11) - is a diagnostic characteristic of root-knot nematode infection. On fibrous roots, gall size may range from a few small, spherical swellings to large, tumorous swellings (Figure 12). Similarly, galling on storage roots may range from small dimples to big, mottled bumps (Figure 11). Galling and other symptoms are often more severe when initial nematode soil infestation is greater, when samples are taken later in the year as damage accumulates, when more susceptible cultivars are grown, and when environmental conditions (drought, disease, extreme heat, etc.) stress the plants. In severe cases, infected tubers may have decayed regions (Figure 14) and be more susceptible to secondary infection by diseases. Storage root cracking may also occur, although this is infrequent in modern cultivars when common root-knot nematodes are present. Other factors, such as environmental stress or reniform nematode infestation can also induce growth cracks. Belowground symptoms tend to be more severe when the guava rootknot nematode is present. Galling can be more prolific, and storage root cracking (Figure 15) tends to be more common with this nematode. Widespread and prolific symptoms on a resistant cultivar are further indicators that guava rootknot nematode may be present. Diagnosis by a professional nematology lab, as described in the section below, is needed to determine which root-knot nematode species (guava, southern, or another root-knot nematode) is present.

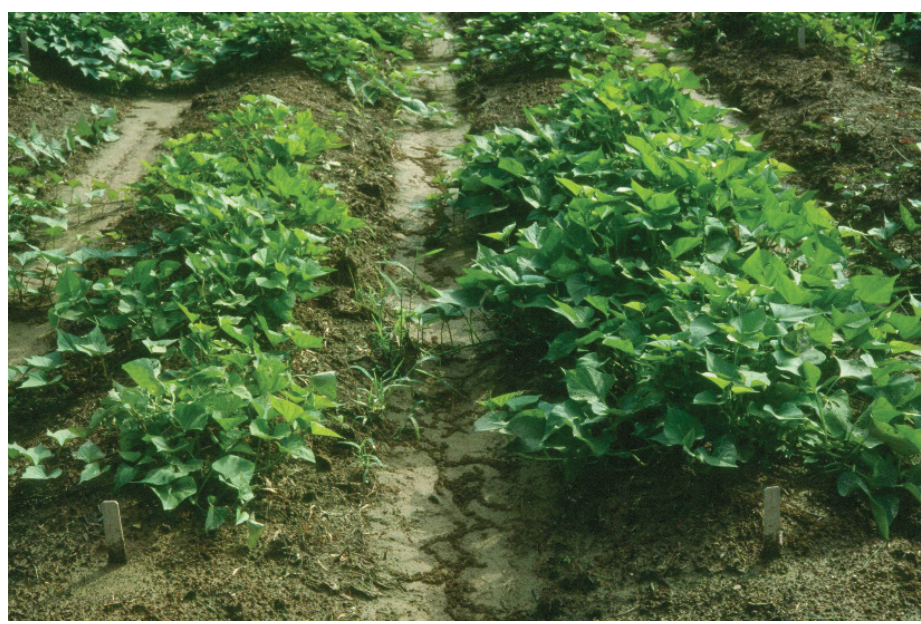

Figure 7. Reduced vine growth (left) due to severe reniform nematode pressure in a research trial. The more vigorous plot on the right is fumigated, so it has less reniform nematode pressure. Credits: Christopher Clark, LSU; used by permission

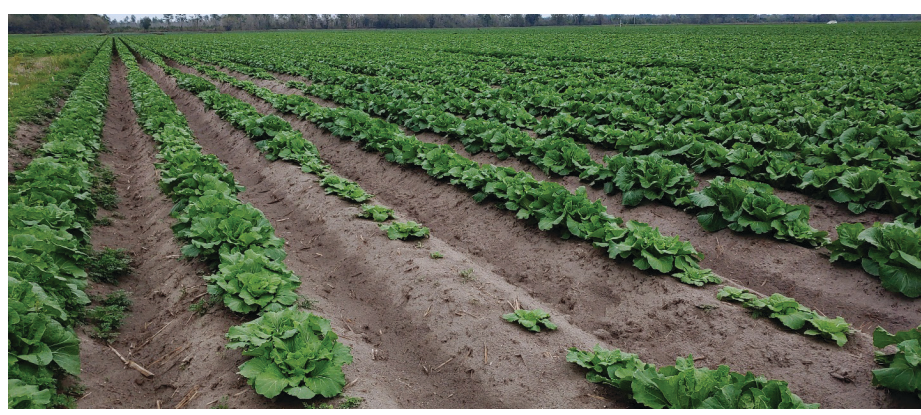

Figure 8. Plant stunting caused by root-knot nematode (Meloidogyne spp.) in Napa cabbage. Symptoms have an irregular, patchy field distribution characteristic of biological disease agents, such as nematodes.

Credits: Zane Grabau, UF/IFAS 
Symptoms of reniform nematode infestation are often generalized and difficult to detect. Reniform nematode infestation causes general stunting of the root system and delayed development (Figure 16). Reniform nematode infestation can induce storage root cracking. While this symptom is infrequent, cracks tend to develop early and result in deep fissures by the end of the year (Figure 17). Sting nematode can be very injurious to many crops, causing infected plants to form a tight mat of short roots that are often swollen at the tips (Figure 18). New root ends are often killed by heavy infestations, leaving pruned, necrotic (brown and dying) root tips (Figure 19).

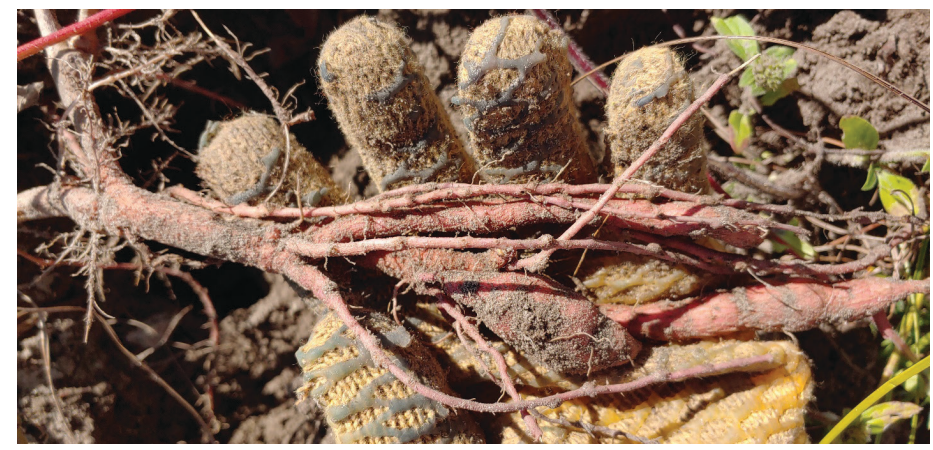

Figure 9. Extensive galling (roughly circular swellings) from southern root-knot nematode on fibrous roots and developing storage roots at midseason.

Credits: Zane Grabau, UF/IFAS

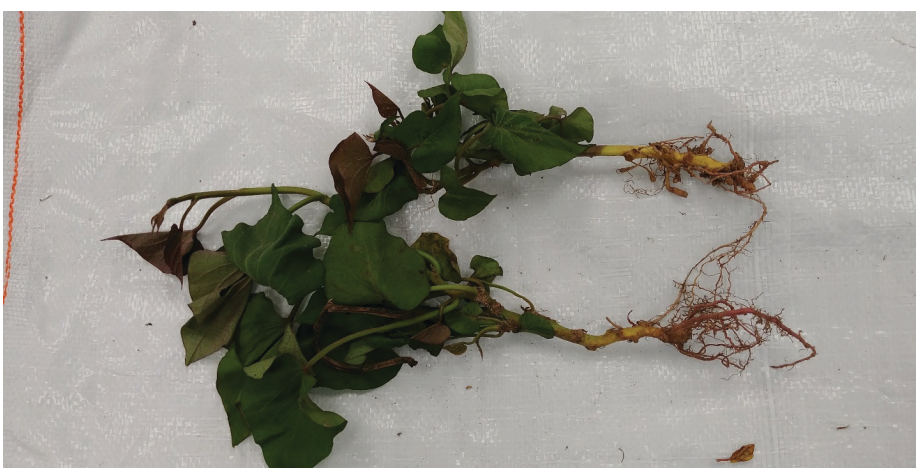

Figure 10. Severe galling from root-knot nematodes on fibrous roots emerging from young sweet potato slip (right) compared with a healthier plant (left) with a more robust, branched root system. Credits: Zane Grabau, UF/IFAS

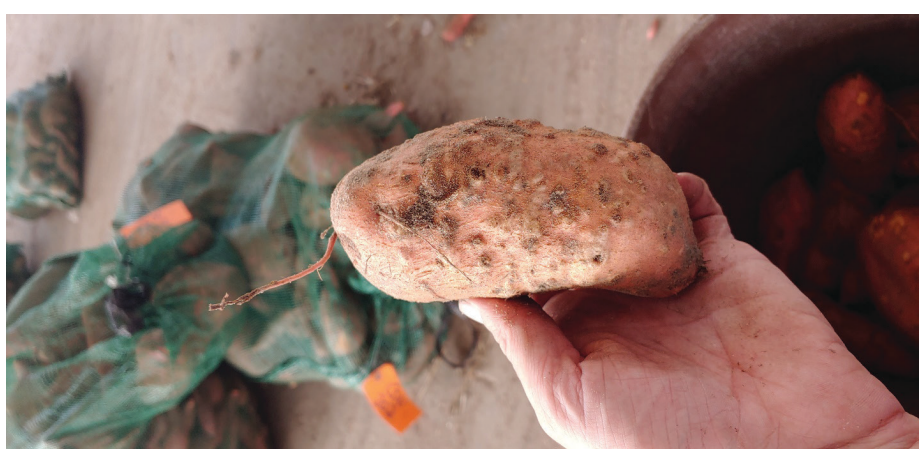

Figure 11. Extensive galling and disfiguration from southern root-knot nematode on a susceptible sweet potato storage root.

Credits: Zane Grabau, UF/IFAS

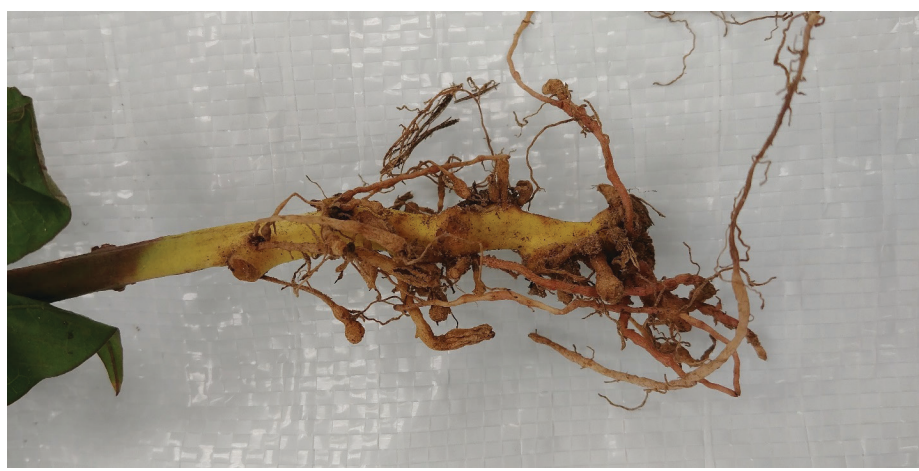

Figure 12. Severe galling (irregularly shaped swellings) of young sweet potato fibrous roots due to root-knot nematode infestation. Credits: Zane Grabau, UF/IFAS

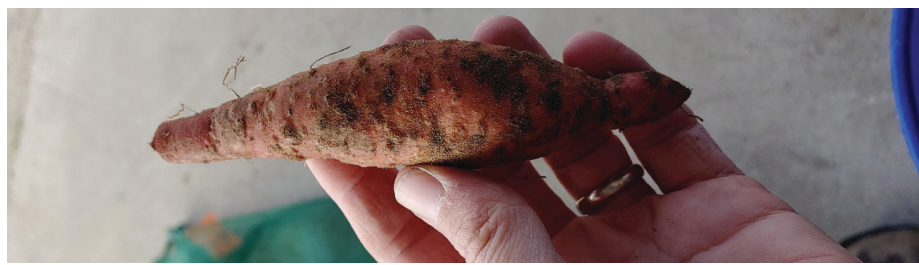

Figure 13. Darker regions of decay and secondary infection along with galling as a result of severe southern root-knot nematode infection. Credits: Zane Grabau, UF/IFAS

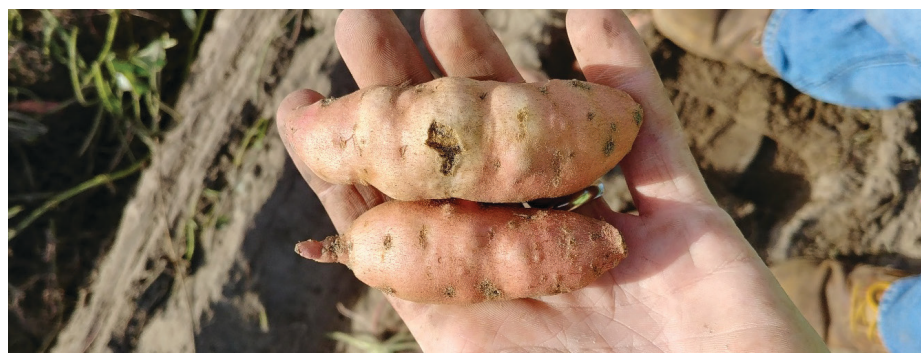

Figure 14. Galling of various sizes_ranging from small dimples to extensive swelling - on young storage roots induced from southern root-knot nematode infestation. The storage root on the right also has a small growth crack, which is an infrequent symptom of common root-knot nematodes.

Credits: Zane Grabau, UF/IFAS

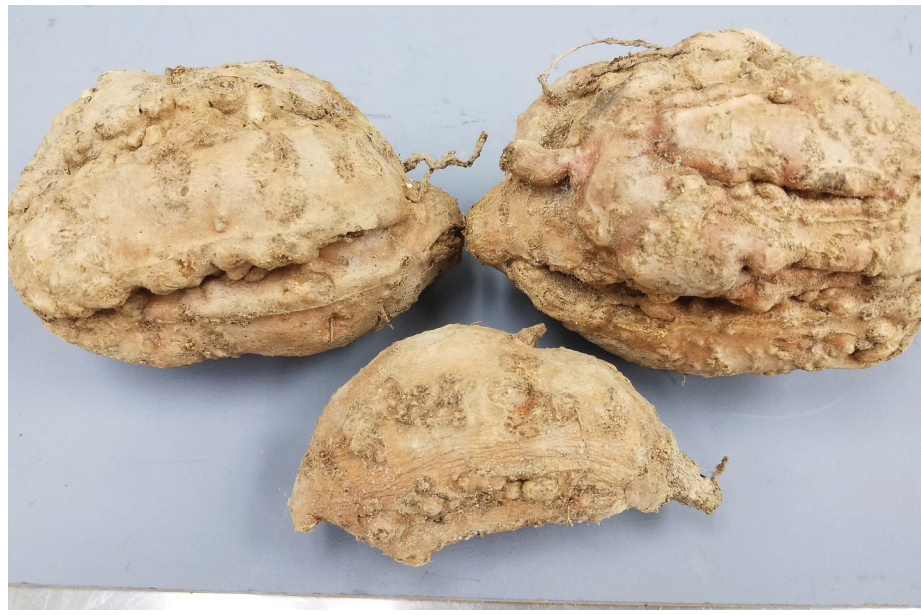

Figure 15. Severe galling and growth cracks on sweet potato storage roots due to the guava root-knot nematode. Galling tends to be more prolific and storage root cracking more common with this nematode than with common root-knot nematodes.

Credits: Charles Overstreet, LSU; used by permission 


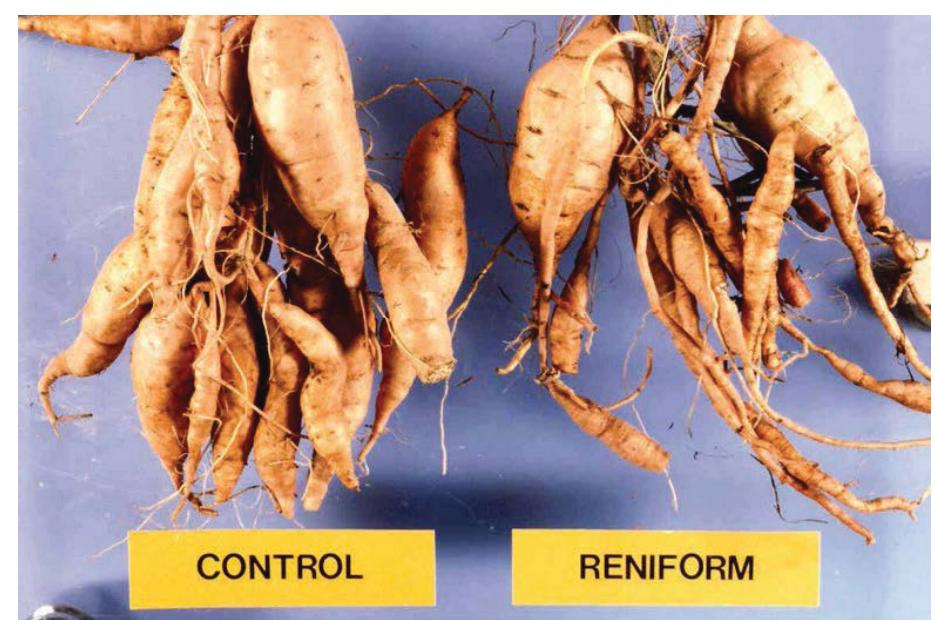

Figure 16. Stunting, delayed development, and decreased storage root production in reniform-infested sweet potato (right) compared with uninfested.

Credits: Charles Overstreet, LSU; used by permission

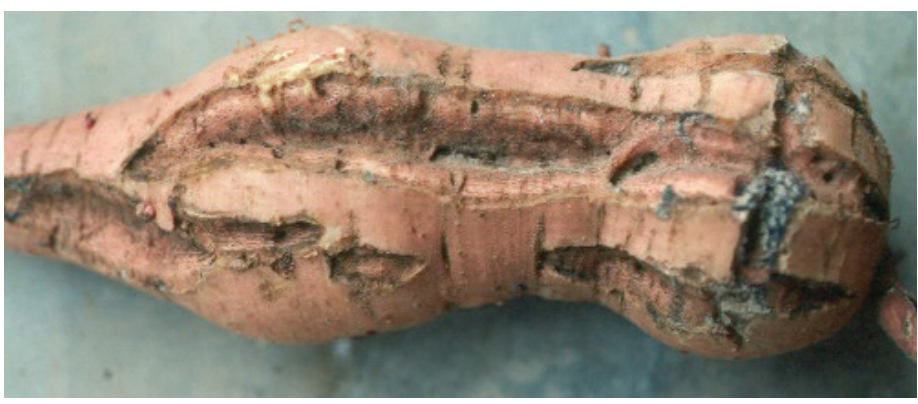

Figure 17. Deep growth cracks on storage root induced by reniform nematode infestation. Growth cracks are an infrequent symptom of reniform nematode infestation, but they tend to be induced early in the year, resulting in very deep fissures by the end of the year. Credits: Christopher Clark, LSU; used by permission

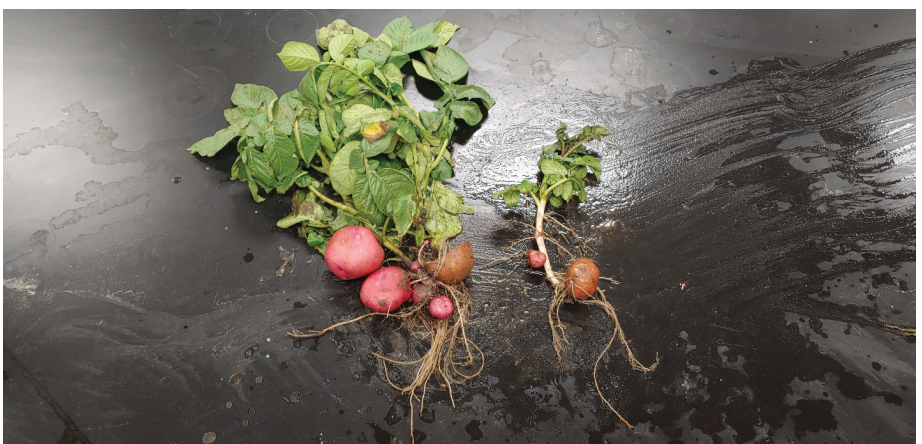

Figure 18. Severe sting nematode infestation in white potato impairs root function, leading to reduced growth (right plant) compared to growth in healthy plants (left plant). The infested plant has a stunted root system with fewer lateral roots.

Credits: Zane Grabau, UF/IFAS

Both reniform and root-knot nematodes are highly damaging to sweet potato, even at low populations, and warrant management any time they are detected. Sting nematode is similarly damaging on most crops, although its interaction with sweet potato is still being determined. The extent of yield loss will vary based on factors such as nematode population density, crop susceptibility, and prevailing environmental conditions. These factors will also affect the timing and severity of damage symptoms, which should be considered when scouting. The greater the nematode abundance, the earlier and more severe the symptoms. Similarly, a very susceptible cultivar (vulnerable to damage by a particular nematode) will sustain more yield loss and may have earlier and more severe symptoms. Environmental stress (drought, high temperatures, low fertility, other diseases, etc.) exacerbates damage.

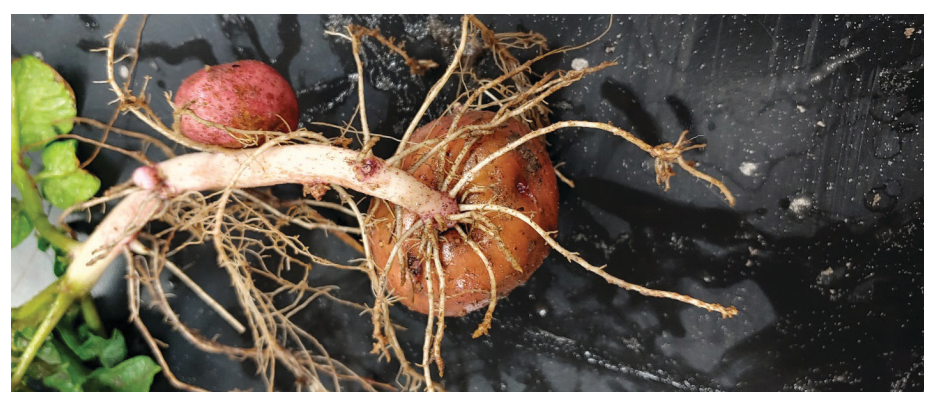

Figure 19. Symptoms of sting nematode damage on white potato roots. The affected root system is stunted, with fewer lateral roots. Lateral roots are pruned, necrotic (browning), and proliferate near the growing tuber, creating a bearded appearance.

Credits: Zane Grabau, UF/IFAS

\section{Field Diagnosis and Sampling}

Soil/tissue sampling and submission to a professional nematode diagnostic lab such as the UF/IFAS Nematode Assay Laboratory is usually required to confirm nematode problems. Nematode sampling is either (1) predictive: determining risk of nematode damage before planting a given crop, or (2) diagnostic: determining if disease symptoms in a crop are caused by nematodes. Predictive samples must be taken before the crop is planted because current nematode management tactics must be deployed at or before planting. Similarly, diagnostic samples are useful for planning management for subsequent crops, but are generally too late to rescue the current crop. Proper collection and submission of samples using the following steps is key for successful nematode diagnosis, and full instructions can be found on the UF/IFAS Nematode Assay Laboratory website. Some key points are summarized here:

1. Always include a soil sample when assessing nematodes because some nematodes (ectoparasites) can only be detected in soil and not roots. Supplement with root samples if possible. Pictures of root and foliar symptoms are also useful.

2. For predictive samples, sampling just before harvest of the previous crop is best because nematode abundances are greatest at that time. Take diagnostic samples when symptoms appear. 
3. Collect samples from 10 to 20 field points from an area of less than 5 acres (predictive) or in the area of symptomatic, but not dead, plants (diagnostic).

4. Sample soil from the rooting zone (within a few inches of stems to at least 8 inches deep) where nematode abundances are greatest.

5. After collection, avoid overheating, drying, and mechanical damage-handle bags gently and avoid tossing or crushing them. Samples can be stored for a few hours at room temperature, but keep them out of sun and extreme heat. Using closed plastic bags helps with moisture retention if the bags are stored properly. If storing bags overnight, refrigerate them.

6. Long delivery may subject samples to extreme temperatures. Avoid weekend shipping and use the fastest feasible delivery method.

\section{Root samples should be collected in a similar manner,} except that fewer point samples (2-5) are realistic. Roots may rot in excess moisture, so do not surround samples with moist material. Send roots surrounded with some soil—provides moderate moisture-or bare.

For each routine sample submitted, the UF/IFAS Nematode Assay Lab will provide a report of the genera (root-knot nematode, reniform nematode, etc.) and quantity of plant-parasitic nematodes in each sample, as well as an assessment of damage risk and management recommendations. Further testing is required to determine the particular species of root-knot nematode in a field (guava root-knot nematode, southern root-knot nematode, etc.), which may influence cultivar selection. The UF/IFAS Nematode Assay Lab can conduct these tests, and they are easiest to complete when root-knot nematode-infected root material is provided. Contact your local Extension agent or Z. J. Grabau for assistance with nematode sampling or for a field consultation.

\section{Nematode Management}

Nematode management strategies rely onreducing nematode abundances to reduce crop damage or choosing aresistant cultivar that avoids most or all damage from a particular nematode. The primary nematode management strategies include (1) use of resistant or tolerant cultivars, (2) crop rotation and other cultural practices, (3) nematicide application, and (4) biological control. When possible, multiple management strategies should be integrated as part of a systems approach.

\section{Cultivar and Transplant Selection}

Use nematode-free transplants to avoid compromising production. Planting slips (cut plant stems) free of roots or soil is the best way to ensure transplants are not infested with nematodes. Avoid planting storage root pieces or slips with roots or soil as theymay contain nematodes. If material with soil or roots is used, ensure these materials are grown in sterilized medium or field soil that is properly managed for nematodes, ideally with a fumigant.

Cultivars with resistance to southern root-knot nematode are available (Table 1). These cultivars both slow southern root-knot nematode reproduction and reduce damage from that nematode (Figure 20). The level of resistance varies by cultivar, with the most common cultivar in Florida, Covington, only offering moderate resistance. Some nematode reproduction and yield loss still occurs on moderately resistant cultivars, so additional crop rotation or nematicide application is generally needed for sufficient management (Johnson et al. 1992). Boniato cultivars commonly grown in Florida are not resistant, but two resistant Boniato cultivars (Liberty and Bonita) are available (Jackson et al. 2011). None of the resistant cultivars are effective against guava root-knot nematode (Brito et al. 2020). Beauregard is susceptible while Jewel and Hernandez are resistant to Javanese root-knot nematode (Cervantes-Flores 2002), but reaction to this nematode is not reported for most cultivars. Many cultivars are not susceptible to peanut root-knot nematode (Cervantes-Flores 2002), which suggests that this common root-knot nematode may not be a common problem for sweet potato. Resistance to any other nematodes has not been identified in commercial sweet potato cultivars.

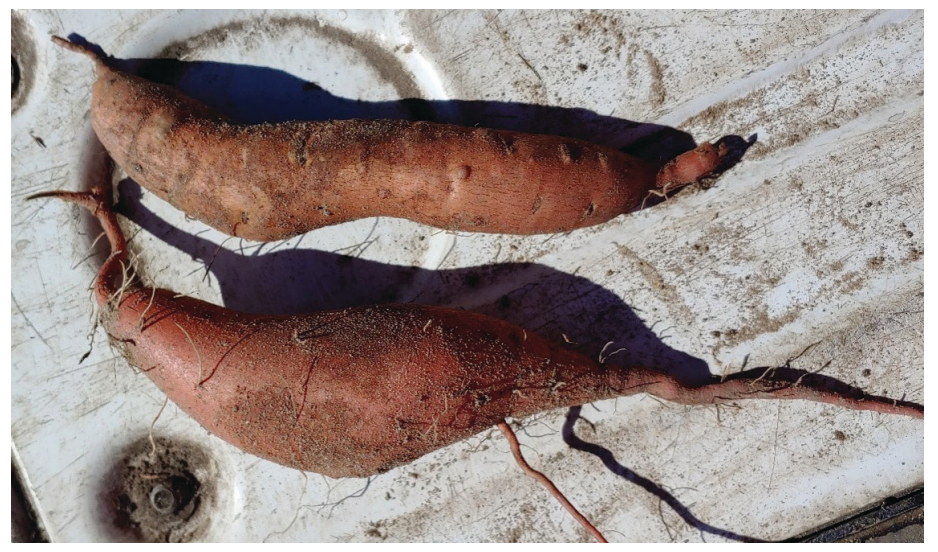

Figure 20. A cultivar (Covington) resistant to southern root-knot nematode free of galling (left) compared with a susceptible variety (Orleans) with wart-like galls from southern root-knot nematode on developing storage roots (right).

Credits: Zane Grabau, UF/IFAS 


\section{Crop Rotation}

Rotating poor or non-host crops with susceptible cash or cover crops is an important practice for nematode management. A poor or non-host supports little or no reproduction of a particular nematode, so nematode populations decrease, reducing damage to subsequent susceptible crops. Susceptibility varies based on the particular nematodecrop combination, so an ideal rotation will vary based on the species of nematode(s) in a particular field (Table 2). Certain crops-such as sunn hemp-also produce allelochemicals that may actively reduce nematode populations. Nematodes may still feed on crops that produce allelochemicals, so host status is important to consider. The amount of time a field needs to be rotated to a nonhost crop to reduce nematode populations below a damaging level will vary based on many factors including initial nematode populations, environmental conditions, and other nematode management practices used. If implemented alone, multiple seasons of a nonhost crop are often needed to reduce nematode populations below a damaging level. For more information on cover crops, see these publications on Florida cover crop production (Wright et al. 2017) and cover crops for root-knot nematode (Gill and McSorley 2017). Also see nematode management using sunn hemp (Wang and McSorley 2018a), cowpea (Wang and McSorley 2018b), and sorghum-sudangrass (Dover et al. 2018).

\section{Other Cultural Practices}

Proper weed management is an important component of nematode management because weeds can serve as hosts for plant-parasitic nematodes and increase or maintain populations during fallow or when a nonhost crop is grown. For example, nutsedge, pigweed, and lambsquarters, among many others, are generally good hosts of root-knot nematodes. Additionally, crops should be terminated by herbicide application or tillage as soon as possible after a crop is harvested. If crops are left in the field after harvest, nematodes can continue to reproduce on their roots. Tillage may contribute to reducing nematode abundances because it heats, dries, and mechanically disturbs the soil as well as destroying potential host plants. Finally, any practices that promote plant health, such as proper irrigation, maintenance of soil fertility, and management of other diseases, may increase plant tolerance to nematodes.

\section{Chemical Control}

Most fields in Florida should be treated with nematicides to improve sweet potato production. Nematicide application reduces nematode populations temporarily, reducing nematode infection and crop damage. When a susceptible crop is grown after nematicide application, nematode populations will eventually begin to increase again. For this reason, nematicide application generally must be repeated before each season a susceptible crop is grown.

\section{FUMIGANT NEMATICIDES}

Fumigants are pesticides that move through the soil as gases (Table 3). Typically, the best-performing fumigants are the most effective chemical option for nematode management in Florida. Many fumigants are broad-spectrum-they may have activity against nematodes, fungal or bacterial pathogens, and weeds. Current fumigants do not provide consistently excellent control of all of these pests (Table 4), so combinations of chemistries or management strategies are often needed for pest management. Fumigants move through the soil relatively quickly - a matter of hours or days-and must contact nematodes to kill them. Therefore, successful fumigation relies on sufficient coverage of a broad swath of soil. Because of this, soil conditions and application techniques affect fumigant performance. Most of these practices are now regulated through EPA Good Agricultural Practices and specified on fumigant labels. In brief, environmental conditions such as soil moisture, temperature, and plant residue affect fumigation. Mechanical factors such as fumigation depth, spacing, and soil sealing are also critical. Allow proper setback time between fumigation and planting - as specified on product labelsin order to avoid crop injury from fumigant residues.

\section{NON-FUMIGANT NEMATICIDES}

Non-fumigant nematicides are liquid or granular products that move through the soil in water. Various non-fumigant nematicides are currently registered for use in sweet potatoand can be applied by various means intended to incorporate the nematicides into the rooting zone of the soil (Table 5). Non-fumigant nematicides generally provide amore narrow spectrum of activity than fumigants, primarily targeting nematodes, although certain products also may have efficacy against certain insects (Majestene, Mocap 15G and Vydate L) or certain fungal pathogens (Velum). Efficacy of non-fumigants varies by product, but non-fumigants are generally less effective than fumigants for control of most nematodes (Table 5). Non-fumigant nematicides work by coming into contact with nematodes in the soil, or, if the product has systemic activity, by being taken up by the plant (Table 6). Therefore, the ability of a product to dissolve and move in water (solubility) and the length of time it takes for the compound to break down (persistence) greatly influence the efficacy of non-fumigants. Mobile non-fumigants (Mocap,Vydate L, and Nimitz) are likely to come in contact with nematodes in the soil more quickly 
than poorly mobile non-fumigants. Very mobile products (particularly Vydate L) also move out of the rooting zone more quickly, particularly with excess rainfall, which can reduce efficacy. A highly persistent nematicide (Velum) will stay in the soil longer, increasing exposure to nematodes. Human toxicity of these products, and thus required handler precautions, also vary by nematicide.

In addition to product characteristics, application methods and soil conditions will greatly influence nematicide efficacy. Always refer to the latest label instructions for proper application procedures. In general, non-fumigants are most effective when they are uniformly applied to soil and targeted toward the future rooting zone of the plant, where they will contact nematodes or be absorbed by the plant. Non-fumigant materials work best in moist soils. Proper tillage-particularly for more immobile productsand irrigation are also critical in order to thoroughly mix non-fumigants into the soil where crops will be grown.

\section{Biological Control}

Biological control uses living organisms to manage pests. Biological control organisms used against nematodes either produce chemicals detrimental to nematodes or directly parasitize nematodes. One method of biological control is an inundative approach where biological control organisms are introduced to the field, generally as a commercial product. MeloCon WG is a biological control product listed in Tables 5 and 6 as it is a formulation of live Purpureocillium lilacinum fungi. Efficacy depends not only on proper distribution in the soil but conditions (such as soil moisture) being conducive for the live organisms. A second approach to biological control is making use of biological control organisms that are native to soil. Many biological control organisms are known to reside in soil, and there are field locations suppressive to nematodes (nematode populations maintained lower than expected despite susceptible crop). Factors such as avoiding broad-spectrum pesticides, avoiding tillage, increasing organic matter input (cover crops or amendments), and increasing crop monoculture may stimulate inherent biological control. However, work is ongoing to channel natural biological control processes into consistent nematode management.

\section{References}

Brito, J. A., J. Desaeger, and D.W. Dickson. 2020. "Reproduction of Meloidogyne enterolobii on Selected Root-Knot Nematode Resistant Sweetpotato (Ipomoea batatas)

Cultivars." Journal of Nematology 52: e2020-63. https://doi. org/10.21307/jofnem-2020-063.
Cervantes-Flores, J. C., G. C. Yencho, and E. L. Davis. 2002. "Host Reactions of Sweetpotato Genotypes to Root-Knot Nematodes and Variation in Virulence of Meloidogyne incognita Populations." HortScience 37:1112-1116. https:// doi.org/10.21273/HORTSCI.37.7.1112

Crow, W. T., D. P. Weingartner, D. W. Dickson, and R. McSorley. 2001. "Effect of Sorghum-Sudangrass and Velvetbean Cover Crops on Plant-Parasitic Nematodes Associated with Potato Production in Florida." Journal of Nematology 33: 285-288.

Crow, W. T. 2018. "Sting Nematode, Belonolaimus longicaudatus Rau (Nematoda: Secernentea: Tylenchida: Tylenchina: Belonolaimidae: Belonolaiminae)." EENY239/ IN395. EDIS 2003 (16). https://doi.org/10.32473/ edis-in395-2001.

Crow, W. T. 2013. "Effects of a Commercial Formulation of Paecilomyces lilacinus Strain 251 on Overseeded Bermudagrass Infested with Belonolaimus longicaudatus." Journal of Nematology 45: 223.

Desaeger, J. A., and T. T. Watson. 2019. "Evaluation of New Chemical and Biological Nematicides for Managing Meloidogyne javanica in Tomato Production and Associated Double Crops in Florida." Pest Management Science 75: 3363-3370. https://doi.org/10.1002/ps.5481

Dittmar, P. J., E. J. McAvoy, R. Raid, H. A. Smith, B. Wells, J. Buezelin, J. Desaeger, L. Beuzelin, Julien, Peter J. Dittmar, Richard N. Raid, Hugh A. Smith, Bonnie Wells, Johan Desaeger, Lincoln Zotarelli, Shouan Zhang, Qingren Wang, and Craig Frey. 2021. "Chapter 15. Root Crop Production in Florida: HS965/CV300, Rev. 4/2021”. EDIS 2021 (VPH). https://doi.org/10.32473/edis-cv300-2021.

Dover, K., K. H. Wang, and R. McSorley. 2018. Nematode Management Using Sorghum and Its Relatives. ENY-716. Gainesville: University of Florida Institute of Food and Agricultural Sciences. https://edis.ifas.ufl.edu/in531

Gill, H. K., and R. McSorley. 2017. Cover Crops for Managing Root-Knot Nematodes. ENY-063. Gainesville: University of Florida Institute of Food and Agricultural Sciences. https://edis.ifas.ufl.edu/in892

Grabau, Z. J., and C. Liu. 2019a. "Fumigant and Non-Fumigant Nematicides for Root-Knot Nematode Management in Florida Tomato, 2018." Plant Disease Management Reports 13: N004. http://www.plantmanagementnetwork.org/pub/ trial/PDMR/volume13/ 
Grabau, Z. J., and C. Liu, C. 2019b. "Impact of Nematicide Application on Root-Knot Nematode Management in Florida Spring Watermelon." Plant Disease Management Reports 13: N006. http://www.plantmanagementnetwork. org/pub/trial/PDMR/volume13/

Grabau, Z. J., J. W. Noling, and P. A. Navia Gine. 2019. "Fluensulfone and 1,3-Dichloroprene for Plant-Parasitic Nematode Management in Potato Production." Journal of Nematology 51: UNSP e2019-38. https://doi.org/10.21307/ jofnem-2019-038

Hewlett, T. E., D. W. Dickson, D. J. Mitchell, and M. E. Kannwischer-Mitchell. 1988. "Evaluation of Paecilomyces lilacinus as a Biocontrol Agent of Meloidogyne javanica on Tobacco." Journal of Nematology 20: 578.

Jackson, D. M., H. F. Harrison, J. A. Thies, J. R. Bohac, and J. D. Mueller. 2011. "Liberty' Dry-fleshed Sweetpotato." HortScience 46: 125-129. https://doi.org/10.21273/

HORTSCI.46.1.125

Johnson, A. W., C. C. Dowler., N. C. Glaze, R. B. Chalfant, and A. M. Golden. 1992. "Nematode Numbers and Crop Yield in a Fenamiphos-Treated Sweet Corn-Sweet Potato-Vetch Cropping System." Journal of Nematology 24: 533-539.

LaBonte, D. R., P. W. Wilson, A. Q. Villordon, and C. A. Clark. 2008. "'Evangeline' Sweetpotato." HortScience 43: 258-259. https://doi.org/10.21273/HORTSCI.43.1.258

Liu, C., and Z. J. Grabau. 2019. "Nematode Management at Different Nematicide Application Time in North Florida Tomato, 2018." Plant Disease Management Reports 13: N010. http://www.plantmanagementnetwork.org/pub/trial/ PDMR/volume13/

Rhoades, H. L. 1987. "Effects of Fumigant and Nonfumigant Nematicides on Nematode Populations and Yields of Broccoli and Squash in Florida." Nematropica 17: 193-198.

Rodriguez-Kabana, R., J. Pinochet, D. G. Robertson, and L. Wells. 1992. "Crop-Rotation Studies with Velvetbean (Mucuna deeringiana) for the Management of Meloidogyne spp." Journal of Nematology 24: 662-668.

Rodriguez-Kabana, R., D. B. Weaver, D. G. Robertson, R. W. Young, and E. L. Carden. 1990. "Rotations of Soybean with 2 Tropical Legumes for the Management of Nematode Problems." Nematropica 20: 101-110.
Smith, T. P., C. Overstreet, C. Clark, M. Sistrunk. 2017. Nematode Management: Louisiana Sweet Potato Production. Pub. 3075. Baton Rouge: Lousiana State University Agricultural Center. https://www.lsuagcenter.com/ /media/system/ 7/2/7/6/7276d6f4eaffd72889570302118e59ce/p3075_nematodemgmtlasweetpotatorev_ai0917tsmith_final2pdf.pdf

United States Department of Agriculture-National Agricultural Statistics Service. 2020 Vegetables 2019 Summary: February 2020. Washington D.C.: United States Department of Agriculture-National Agricultural Statistics Service.

Wang, K. H. 2019. "Reniform Nematode, Rotylenchulus reniformis Linford and Oliveira (Nematoda: Tylenchida: Hoplolaimidae: Rotylenchulinae)." ENY-210. EDIS 2019. https://edis.ifas.ufl.edu/in367

Wang, K. H., and R. McSorley. 2018a. "Management of Nematodes and Soil Fertility with Sunn Hemp Cover Crop." ENY-717. EDIS 2018. https://edis.ifas.ufl.edu/ng043

Wang, K. H., and R. McSorley. 2018b. "Management of Nematodes with Cowpea Cover Crops." ENY-712. EDIS 2018. http://edis.ifas.ufl.edu/in516

Watson, T. T., and J. A. Desaeger. 2019. "Evaluation of Non-Fumigant Chemical and Biological Nematicides for Strawberry Production in Florida." Crop Protection 117:100-107. https://doi.org/10.1016/j.cropro.2018.11.019

Wright, D. L., C. Mackowiak, and A. Blount. 2017. Cover Crops. SS-AGR-66. EDIS 2017. https://edis.ifas.ufl.edu/ aa217

Yencho, G. C., K. V. Pecota, J. R. Schultheis, Z. VanEsbroeck, G. J. Holmes, B. E. Little, A. C. Thornton, and V. Truong. 2008. "'Covington' Sweetpotato." HortScience 43:1911-1914. https://doi.org/10.21273/ HORTSCI.43.6.1911 
Table 1. Susceptibility of cultivars to southern root-knot nematode as sorted by type.1

\begin{tabular}{|c|c|c|c|}
\hline Sweet Potato Cultivar & $\begin{array}{l}\text { Resistance to Southern Root- } \\
\text { Knot Nematode }\end{array}$ & Skin Color & Flesh Color \\
\hline & \multicolumn{2}{|c|}{ Conventional Orange-fleshed Cultivars } & \\
\hline Beauregard ${ }^{2}$ & Susceptible $^{3}$ & Copper & Orange \\
\hline Orleans & Susceptible & Light rose & Orange \\
\hline Covington ${ }^{2}$ & Moderately resistant & Light rose & Orange \\
\hline Jewel & Moderately resistant ${ }^{3}$ & Light orange & Orange \\
\hline Bellevue & Highly resistant & Copper & Orange \\
\hline \multirow[t]{2}{*}{ Hernandez ${ }^{2}$} & Highly resistant $^{3}$ & Orange & Orange \\
\hline & \multicolumn{2}{|c|}{ Specialty Cultivars } & \\
\hline Violet Queen $^{2}$ & Unknown & Purple & Purple \\
\hline Georgia Red & Moderately resistant & Red & Orange \\
\hline Evangeline $^{2}$ & Moderately resistant & Dark rose & Orange \\
\hline Charleston scarlet & Resistant & Red & Orange \\
\hline Murasaki-29 & Highly resistant & White & Purple \\
\hline \multirow[t]{2}{*}{ Burgundy } & Highly resistant & Red & Orange \\
\hline & \multicolumn{2}{|c|}{ Boniato (dry) Cultivars } & \\
\hline Campeon $^{2}$ & Unknown & Light red & White \\
\hline Homestead & Unknown & Cream & White \\
\hline New Boniato ${ }^{2}$ & Unknown & Cream & White \\
\hline Picadito $^{2}$ & Susceptible & Dark red & White \\
\hline Liberty & Resistant & Red & Cream \\
\hline Bonita & Highly resistant & Cream & White \\
\hline
\end{tabular}


Table 2. Host status of common cash and summer cover crops for plant-parasitic nematodes important for Florida sweet potato production. $^{1}$

\begin{tabular}{|c|c|c|c|c|}
\hline & $\begin{array}{c}\text { Southern } \\
\text { Root-Knot Nematode }\end{array}$ & $\begin{array}{c}\text { Javanese } \\
\text { Root-Knot Nematode }\end{array}$ & $\begin{array}{l}\text { Guava Root-Knot } \\
\text { Nematode }\end{array}$ & Sting Nematode \\
\hline \multicolumn{5}{|l|}{ Cash Crops } \\
\hline Cabbage & Host & Varies & Host & Host \\
\hline Corn & Host & Host & Poor host & Host \\
\hline Cotton & Host & Poor host & Host & Host \\
\hline Peanut & Poor host & Host & Poor host & Varies \\
\hline Potato & Host & Host & Host & Host \\
\hline Soybean & Host $^{2}$ & Host & Host & Host \\
\hline Tomato & Host $^{2}$ & Host $^{2}$ & Host & Host \\
\hline Watermelon & Host & Host & Host & Unknown ${ }^{3}$ \\
\hline \multicolumn{5}{|l|}{ Summer Cover Crops } \\
\hline Sorghum-sudangrass & Poor host & Poor host & Poor host & Host \\
\hline Sunn hemp & Poor host & Poor host & Poor host & Poor host \\
\hline Cowpea & Host $^{2}$ & Host $^{2}$ & Host & Host \\
\hline Hairy indigo & Poor host & Poor host & Unknown & Poor host \\
\hline Jointvetch & Poor host & Poor host & Unknown & Unknown \\
\hline \multicolumn{5}{|l|}{ Winter Cover Crops } \\
\hline Oats & Poor host & Poor host & Poor host & Host \\
\hline Rye & Poor host & Poor host & Poor host & Host \\
\hline Wheat & Varies & Poor host & Poor host & Host \\
\hline \multicolumn{5}{|c|}{$\begin{array}{l}\text { Host }=\text { good host which will increase populations; Poor host= poor/non-host which will decrease populations; Varies= susceptibility varies by } \\
\text { cultivar or report (may suggest an intermediate level of susceptibility). Within species, different nematode races/populations may exist and } \\
\text { relationships may differ for specific nematode populations and crop cultivars. } \\
{ }^{1} \text { Information is based on observations and literature at the time of publication (Rodriguez-Kabana et al. 1990; Rodriguez-Kabana et al. 1992; } \\
\text { Crow et al. 2001; Gill and McSorley 2017; Dover et al. 2018; Wang and McSorley 2018a,b). } \\
{ }^{2} \text { Resistant cultivars are available. Most cultivars are good hosts. } \\
{ }^{3} \text { Watermelon has been observed anecdotally to be a poor host or to tolerate sting nematode, but formal research is needed. }\end{array}$} \\
\hline
\end{tabular}

Table 3. Fumigant nematicides for sweet potato in Florida.

\begin{tabular}{|c|c|c|c|}
\hline \multirow[b]{2}{*}{ Nematicide $^{2}$} & \multicolumn{2}{|c|}{ Broadcast Application Rates' } & \multirow[b]{2}{*}{ In-the-Row Applications } \\
\hline & $\begin{array}{l}\text { Gallons Per } \\
\text { Acre }\end{array}$ & $\begin{array}{l}\text { fl oz/1000 ft/ Chisel } \\
\text { Spaced } 12 \text { in apart }\end{array}$ & \\
\hline Telone $\|^{3}$ & 9 to 12 & 26 to 35 & May be concentrated in row. Do not exceed broadcast rate. \\
\hline Telone $\mathrm{C}-17^{3}$ & 10.8 to 17.1 & 31.8 to 50.2 & May be concentrated in row. Do not exceed broadcast rate. \\
\hline Telone $\mathrm{C}-35^{3}$ & 13 to 20.5 & 38.2 to 60.2 & May be concentrated in row. Do not exceed broadcast rate. \\
\hline Pic-Clor 60 & 19 to 31.5 & 57 to 90 & May be concentrated in row. Do not exceed broadcast rate. \\
\hline Pic 100 & 150 to $350 \mathrm{lb}$ & - & May be concentrated in row. Do not exceed broadcast rate. \\
\hline Vapam HL & 75 & - & $\begin{array}{l}\text { Must proportionally reduce rates and modify flow for drip or in-row chisel application. } \\
\text { See label. }\end{array}$ \\
\hline KPam HL & 60 & - & $\begin{array}{l}\text { Must proportionally reduce rates and modify flow for drip or in-row chisel application. } \\
\text { See label. }\end{array}$ \\
\hline Dominus & 40 & - & $\begin{array}{l}\text { Must proportionally reduce rates and modify flow for drip or in-row chisel application. } \\
\text { See label. }\end{array}$ \\
\hline \multicolumn{4}{|c|}{$\begin{array}{l}{ }^{1} \text { Rates provided only for mineral soils. Higher rates may be allowed for heavier textured (loam, silt, clay) or highly organic soils. At the time of } \\
\text { publication, rates are believed to be correct for products named and similar products of other brand names. However, the grower has the final } \\
\text { responsibility to see that each product is used legally. Read the label of the product to be sure that you are using it properly. } \\
{ }^{2} \text { All of the fumigants mentioned are for retail sale and use only by state-certified applicators or persons under their direct supervision. New } \\
\text { supplemental labeling for the Telone products must be in the hands of the user at the time of application. } \\
{ }^{3} \text { Higher application rates are allowed in the presence of cyst-forming nematodes. }\end{array}$} \\
\hline
\end{tabular}


Table 4. Generalized summary of maximum use rate and relative effectiveness of various soil fumigant alternatives to methyl bromide for nematode, soilborne disease, and weed control in Florida.

\begin{tabular}{|c|c|c|c|c|}
\hline \multirow[b]{2}{*}{ Fumigant Trade Name ${ }^{1}$} & \multirow[b]{2}{*}{ Active Ingredient } & \multicolumn{3}{|c|}{ Relative Pesticidal Activity } \\
\hline & & Nematode & Disease & Weed \\
\hline Pic 100 & Chloropicrin & Poor & Excellent & Poor \\
\hline Dominus & Allyl isothiocyanate & Poor to good & Poor to good & Poor to good \\
\hline KPam HL & Metam potassium & Fair to good & Fair to good & Fair to good \\
\hline Vapam HL & Metam-sodium & Fair to good & Fair to good & Fair to good \\
\hline Telone II & 1,3-Dichloropropene & Good to excellent & None to poor & Poor \\
\hline Telone C17 & $\begin{array}{l}\text { 1,3-Dichloropropene + } \\
\text { chloropicrin }\end{array}$ & Good to excellent & Good & Poor \\
\hline Telone C35 & $\begin{array}{l}\text { 1,3-Dichloropropene + } \\
\text { chloropicrin }\end{array}$ & Good to excellent & Good to excellent & Poor to fair \\
\hline Pic-Clor 60 & $\begin{array}{l}\text { 1,3-Dichloropropene + } \\
\text { chloropicrin }\end{array}$ & Good to excellent & Good to excellent & Poor to fair \\
\hline
\end{tabular}

Table 5. Non-fumigant products for sweet potato in Florida.

\begin{tabular}{|c|c|c|c|}
\hline $\begin{array}{l}\text { Nematicide Trade Name } \\
\text { (Active Ingredient) }^{1}\end{array}$ & Labeled Rate $^{2}$ & Application Timing & Application Methods \\
\hline $\begin{array}{l}\text { Mocap 15G } \\
\text { (ethoprop) }\end{array}$ & $\begin{array}{l}20-26 \mathrm{lb} / \mathrm{a} \\
(1.6-2.1 \mathrm{lb} / 1000 \mathrm{row}-\mathrm{ft})\end{array}$ & $2-3$ weeks before planting & $\begin{array}{l}\text { Banded (12-15") and } \\
\text { incorporated 2-4" deep in soil }\end{array}$ \\
\hline Mocap EC (ethoprop) & 5.1-6.9 fl oz/100 row-ft & 2-3 weeks before planting & $\begin{array}{l}\text { Banded }\left(12-15^{\prime \prime}\right) \text { and } \\
\text { incorporated } 2-4 " \text { deep in soil }\end{array}$ \\
\hline $\begin{array}{l}\text { Majestene (dead Burkholderia } \\
\text { bacteria) }\end{array}$ & $\begin{array}{l}4-8 \text { quarts/a. Multiple } \\
\text { applications may be made. }\end{array}$ & $\begin{array}{l}\text { Any or all of: } \\
\text { Before planting } \\
\text { At planting } \\
\text { 3. Post-planting }\end{array}$ & $\begin{array}{l}\text { Shank,broadcast spray, banded/ } \\
\text { in-furrow spray, drench, or } \\
\text { chemigation depending on } \\
\text { timing.See label for details. }\end{array}$ \\
\hline $\begin{array}{l}\text { Melocon WG (live Purpureocillium } \\
\text { lilacinus fungi) }^{3}\end{array}$ & 6-9 lb/a per application & $\begin{array}{l}\text { 1. Up to } 21 \text { days before planting } \\
\text { and } \\
\text { 2. At planting }\end{array}$ & $\begin{array}{l}\text { 1. Preplant banded or broadcast } \\
\text { spray. } \\
\text { 2. Drench in transplant water. }\end{array}$ \\
\hline Nimitz (fluensulfone) & $\begin{array}{l}\text { 3.5-7 pt/treated a (banded } \\
\text { applications not to be } \\
\text { concentrated in row) }\end{array}$ & At or before planting & $\begin{array}{l}\text { Broadcast or banded spray. } \\
\text { Incorporate by tillage and irrigate } \\
\text { in, if possible. } \\
\text { Overhead or drip irrigation. }\end{array}$ \\
\hline Velum (fluopyram) & $\begin{array}{l}6.5 \text { to } 6.84 \text { oz/acre per } \\
\text { application. } \\
13.7 \text { oz/acre per year. }{ }^{5}\end{array}$ & Flexible ( $>7$ days before harvest) & $\begin{array}{l}\text { 1. Preplant or postplant drench } \\
\text { 2. Overhead irrigation } \\
\text { 3. In-furrow spray }\end{array}$ \\
\hline Vydate L (oxamyl) & $\begin{array}{l}\text { 1. } 2 \mathrm{gal} / \text { treated a (preplant) } \\
\text { 2. } 1-2 \mathrm{gal} / \mathrm{a} \text { (at-plant) } \\
\text { (No more than } 3 \mathrm{~g} / \mathrm{a} \text { total) }\end{array}$ & $\begin{array}{l}\text { 1. } 7 \text { days or less before planting } \\
\text { 2. At planting }\end{array}$ & $\begin{array}{l}\text { 1. Broadcast or banded spray } \\
\text { incorporated } 4-6 " \text { deep in soil } \\
\text { 2. Drench in transplant water }\end{array}$ \\
\hline \multicolumn{4}{|c|}{$\begin{array}{l}{ }^{1} \text { Provided as guidelines only. Information is subject to changing product registration and labeling. Always read and follow label instructions. } \\
\text { The mention of a product or trade name does not imply endorsement to the exclusion of other products. Ethoprop and oxamyl products are } \\
\text { restricted-use pesticides for use only by state-certified applicators or persons under their direct supervision. } \\
{ }^{2} \text { Do not exceed greatest listed label rate.Only } 1 \text { application per growing season is allowed unless noted otherwise. } \\
{ }^{3} \text { Majestene and Melocon WG are OMRI-listed organic nematicides. }\end{array}$} \\
\hline
\end{tabular}


Table 6. Characteristics of non-fumigant products in Florida sweet potato.

\begin{tabular}{|c|c|c|c|c|c|}
\hline $\begin{array}{l}\text { Trade Names (Active } \\
\text { Ingredient) }\end{array}$ & $\begin{array}{l}\text { Handler Toxicity } \\
\text { Category' }\end{array}$ & $\begin{array}{l}\text { Soil Movement } \\
\text { (Water Solubility) }\end{array}$ & $\begin{array}{l}\text { Persistence in Soil } \\
\text { (Half-Life) }\end{array}$ & Systemic in Plant? & $\begin{array}{c}\text { Relative Efficacy } \\
\text { against Nematodes }\end{array}$ \\
\hline $\begin{array}{l}\text { Mocap } 15 G \text { or EC } \\
\text { (ethoprop) }\end{array}$ & Danger & $\begin{array}{l}\text { High } \\
\text { (843 ppm) }\end{array}$ & $\begin{array}{l}\text { Short } \\
\text { (3-56 days) }\end{array}$ & No & Fair to good \\
\hline $\begin{array}{l}\text { MeloCon WG (live } \\
\text { Paecilomyces fungi) }\end{array}$ & Caution & N/A & $\mathrm{N} / \mathrm{A}$ & No & Poor to fair \\
\hline $\begin{array}{l}\text { Majestene (dead } \\
\text { Burkholderia bacteria) }\end{array}$ & Caution & N/A & N/A & No & Poor to fair \\
\hline Nimitz (fluensulfone) & Caution & $\begin{array}{l}\text { Medium } \\
\text { (545 ppm) }\end{array}$ & $\begin{array}{l}\text { Short } \\
\text { (7-17 days) }\end{array}$ & No & Fair to excellent \\
\hline Velum (fluopyram) & Caution & $\begin{array}{l}\text { Low } \\
\text { (10 ppm) }\end{array}$ & $\begin{array}{l}\text { Long } \\
\text { (162-746 days) }\end{array}$ & $\begin{array}{l}\text { Yes, limited } \\
\text { movement }\end{array}$ & Fair to good \\
\hline Vydate L (oxamyl) & Danger & High (240,000 ppm) & Short (7 days) & Yes & Fair to excellent \\
\hline \multicolumn{6}{|c|}{$\begin{array}{l}\text { "EPA-designated terms on product labels to alert handlers to toxicity hazards. "Danger" is the greatest hazard level, followed by "Warning" and } \\
\text { "Caution." Ethoprop and oxamyl are restricted-use pesticides. } \\
\text { 'Efficacy scale is none to excellent. Efficacy may vary by situation and should be used as a guide only. Most products have not been tested } \\
\text { side-by-side in sweet potato trials. Rating is based on published and unpublished Florida research trials in both sweet potato and other } \\
\text { vegetables (Rhoades 1987; Hewlett et al. 1988; Watson and Desaeger 2019; Grabau et al. 2019; Liu and Grabau 2019; Desaeger and Watson } \\
\text { 2019; Grabau and Liu 2019a; Grabau and Liu 2019b). }\end{array}$} \\
\hline
\end{tabular}

